\title{
LEAKAGE-CAUSE ANALYSIS OF A FLANGE JOINT DESIGNED ACCORDING TO STANDARDS
}

\author{
ANALIZA VZROKOV PUŠČANJA SPOJA PRIROBNICE \\ OBLIKOVANE V SKLADU S STANDARDI
}

\author{
Pavel Lošák, Tomáš Létal, Jiří Buzík, Martin Nad' \\ Brno University of Technology, Faculty of Mechanical Engineering, Technicka 2, 61669 Brno, Czech Republic \\ pavel.losak@fme.vut.cz \\ Prejem rokopisa - received: 2017-07-05; sprejem za objavo - accepted for publication: 2017-21-12
}

doi:10.17222/mit.2017.107

\begin{abstract}
Flange joints and their sealing play an important role in many industries. The gasket performance and its behaviour are influenced by a number of factors, such as non-linear material properties with permanent deformations, assembly procedures and the preparation of sealing surfaces. Additionally, a proper seal function is also affected by the design and strength design of the flanges. Determination of the respective tightening torque needed to achieve a suitable contact pressure between the seal and the flange face is equally important. This paper deals with finite element method (FEM) analyses of a flange joint designed in accordance with the modern standard EN 13445-3 Annex G and examines the influence of operating conditions on the gasket contact pressure. The article also discusses the effects of assembly on the tightness of the joint and the reason for the leakage of the operating medium that took place. The analyses show the effects of operating states on the contact pressures of gaskets and the pre-stressing of bolts. They demonstrate the contact pressure after the application of the pre-stressing of the bolts and its reduction after the temperature-field stabilization due to the start-up of the device. The results of the analyses show that only a relatively small surface of the seal achieves the compression required by the manufacturer to maintain the seal integrity during the application of the tightening forces determined in accordance with EN 13445-3 Annex G. The force of the pre-stressing of the bolts is reduced by approximately $6 \%$ when the normal operation condition is reached. The analyses were performed due to a suspicion of a significant influence of the temperature distribution on flange joints. The main cause of the flange leakage was subsequently revealed by a physical inspection that demonstrated assembly failures when installing gasket 2 . The description of these deficiencies is not a subject of this article.
\end{abstract}

Keywords: flange joint, sealing, gasket, FEM, contact pressure

Spoji prirobnic in njihovo tesnenje igrajo pomembno vlogo v mnogih industrijskih vejah. Lastnosti tesnila in njegovo vedenje je odvisno od mnogih faktorjev, kot so: nelinearne materialne lastnosti s stalno deformacijo, kakor tudi postopek namestitve in tesnilna površina. Dodatno je pravilno tesnenje odvisno tudi od oblike in trdnosti prirobnice. Prav tako je pomembna določitev tesnilnega navora za doseganje primernega kontaktnega tlaka med tesnilom in površino prirobnice. V članku avtorji opisujejo analizo spoja prirobnice s pomočjo metode končnih elementov (FEM; angl.: Finite Element Method), ki je oblikovana v skladu z modernim standardom EN 13445-3 Annex G in preiskuje vpliv delovnih pogojev na kontaktni tlak tesnila. V članku avtorji prav tako razpravljajo o vplivih montaže na tesnost spoja ter podajajo možne razloge za puščanje delovnega medija. $V$ analizi so pokazali, kakšen je vpliv obratovalnih pogojev na kontaktni tlak tesnila in prednapetost pritrdilnih vijakov. Analiza je pokazala, kakšen je kontaktni tlak po predobremenitvi (privijačenju) pritrdilnih vijakov in njegovo zmanjšanje po stabilizaciji temperaturnega polja zaradi zagona naprave. Rezultati analize so pokazali, da že zelo majhna površina tesnila zagotavlja tlak (stisk) zahtevan s strani proizvajalca, da se ohrani integriteta tesnila pri aplikacijah sil tesnenja določenih v skladu s standardom EN 13445-3 Annex G. Začetna pričvrstitev (sila), s katero držijo pritrdilni vijaki, se zmanjša za približno $6 \%$, ko so doseženi normalni delovni pogoji. Avtorji članka so pričujočo analizo izvedli zaradi suma, da na spoj prirobnice pomembno vpliva temperaturna porazdelitev po njem. Pregled in glavni vzrok za puščanje na prirobnici je dodatno podan še v drugem primeru namestitve tesnila. Podane pomanjkljivosti v tem primeru niso predmet tega članka.

Ključne besede: spoj prirobnice, tesnenje, tesnilo, FEM-metoda končnih elementov, kontaktni tlak

\section{INTRODUCTION}

Flange joints are characterized by leakage classes and a number of conditions have to be met to achieve them. The design of flange joints has to follow the standards, but even the compliance with them may not always provide the required sealing. Many variables are included in the design process and not all are taken into account in standardized procedures. Many computational procedures are based on the obsolete Taylor-Forge method, ${ }^{1}$ which suffers from certain flaws, the most important of which is often incorrectly calculated hub stresses. ${ }^{2}$ Therefore, an alternative design method according to C SN EN 13445-3 Annex $\mathrm{G}^{3}$ was used for the design of a flange joint. The use of this approach, as well as of the others, may not, for the sake of many simplifications, sufficiently consider the reality under examination and provide the required flange joint sealing. This problem is continuously faced by the industry. ${ }^{4}$

Although leakage may occur due to many factors, this article investigates leakage due to an insufficient contact pressure on the sealing surfaces. A flange joint undergoes several load-bearing operations. During the assembly, the cold flange connection is tightened to the specified pretension. When the operating media is introduced, an uneven time-dependent temperature field causes significant changes in the stress distribution due 
to an uneven thermal expansion. When the temperature stabilizes, the pretension in the bolts is reduced. Distribution of pressures on the sealing surfaces and the contact-pressure magnitude undergo significant changes. The complex structural behaviour of a joint was thoroughly investigated in the experiment using the finiteelement method (FEM).

\section{GASKET-JOINT CONFIGURATION AND MATERIAL PROPERTIES}

The geometry of flanges, gaskets and bolt is shown in Figure 1. In area 1, steam flows at a temperature of $317^{\circ} \mathrm{C}$ and a pressure of $0.552 \mathrm{MPa}$. In area 2 , steam has a temperature of $107.2^{\circ} \mathrm{C}$ and a pressure of $0.0342 \mathrm{MPa}$. Area 3 indicates the ambient atmosphere, with the temperature considered to be $22{ }^{\circ} \mathrm{C}$ and a pressure of $0.1 \mathrm{MPa}$.

With respect to material properties, ${ }^{5,6}$ flanges and bolts are assumed to be homogenous, isotropic and linearly elastic. Flange materials are shown in Table 1.

Table 1: Flange-joint materials

\begin{tabular}{|c|c|}
\hline flange $-\mathrm{a}$ & $1.0425 \mathrm{P} 265 \mathrm{GH}$ plate and strip, HT:N \\
\hline flange $-\mathrm{b}$ & $1.0553, \mathrm{~S} 355 \mathrm{~J} 0$ flat/long products $^{6}$ \\
\hline bolts & type 8.8 \\
\hline
\end{tabular}

The material of the gaskets is Power graf 3 premium, ${ }^{7}$ with characteristics shown in Figure 2. The sealing of the gasket is guaranteed when the contact pressure is in a range of 20-130 $\mathrm{MPa}$. It is recommended to design a flange joint for at least $26 \mathrm{MPa}$ to assure the tightness.

The gasket exhibits a specific nonlinear behaviour, which can be described using a specialized material model. The material model with linear unloading characteristics of the Power graf 3 premium seal (Figure 2) was used for the gasket in the FEM analysis.

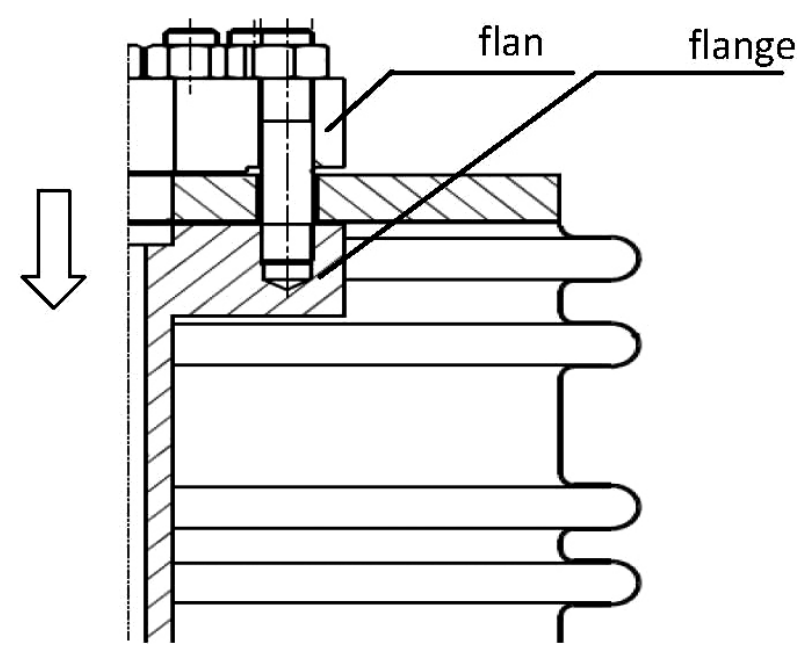

Figure 1: Geometry of the flange joint

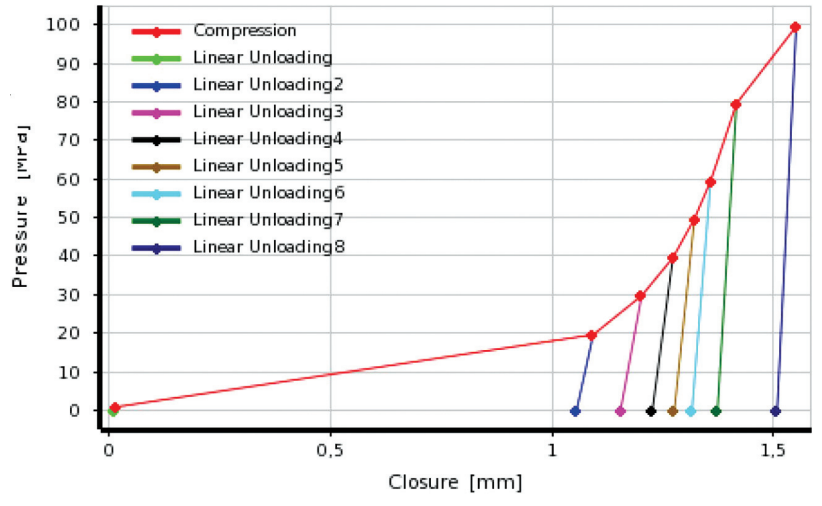

Figure 2: Power graf 3 premium characteristics

\subsection{Finite element model}

\section{Discretization}

As the FEM model, a solid 3D model of "a pie section" of the flange joint was created assuming two planes of symmetry. Figure 3 shows the mesh division used in the FEM analyses for bolted flange joints. The ANSYS software was used to perform the analyses. The solution consisted of a transient thermal analysis with a direct connection to the relevant static structural analyses. The FEM mesh model can be seen in Figure 3.

\section{Element types used}

Solid elements SOLID186 and SOLID187 were used for the discretization of the flanges. Gasket elements INTER195 and a 3-D 8-node linear interface element were used for gasket modelling. The applied pretension of the bolt was simulated using the PRETS179 elements. For the contacts elements, CONTA174 and TARGE170 were used.

\section{Loading and boundary conditions}

Loading and boundary conditions may be divided according to the analysis type. For the transient thermal analysis (Figure 4), convection zones describing a

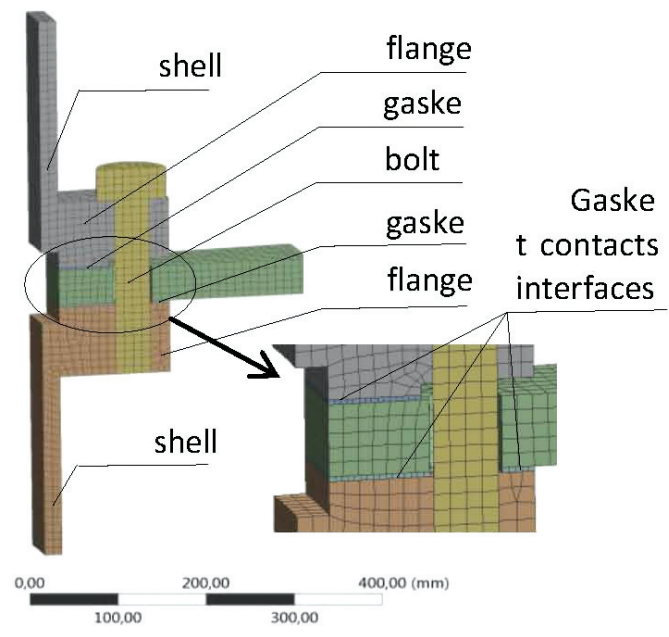

Figure 3: Finite-element-model mesh 
A: Transient Thermal

Transient Thermal

Time: $16000 \mathrm{~s}$

30.6.2017 15:27

A Convection: $102,7^{\circ} \mathrm{C}, 7, \mathrm{e}-004 \mathrm{~W} / \mathrm{mm}^{2} \cdot{ }^{\circ} \mathrm{C}$

B Convection $2: 317,{ }^{\circ} \mathrm{C}, 7, \mathrm{e}-004 \mathrm{~W} / \mathrm{mm}^{2}{ }^{\circ} \mathrm{C}$

C Convection $3: 22,{ }^{\circ} \mathrm{C}, 7,99 \mathrm{e}-006 \mathrm{~W} / \mathrm{mm}^{2} .{ }^{\circ} \mathrm{C}$

D Gasket Mesh Control

E Gasket Mesh Control

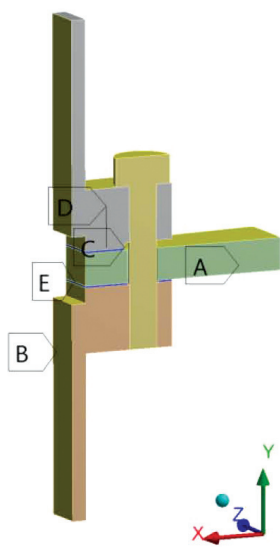

0,00

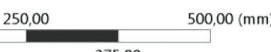

Figure 4: Transient thermal boundary condition

gradual distribution of the temperature were applied across the structure (thermal convections were applied as convection on all three zones (Figure 3)). The aim of the analysis was to obtain the time-dependent response of the structure. To obtain the steady-state distribution of the temperature, the analysis simulated a time interval of $16,000 \mathrm{~s}$.

Static structural analyses were performed for 37 time steps with connected relevant temperature fields. Boundary conditions are summarized in Figure 5. In addition to the temperature, relevant pressures and equivalent pressure forces were applied to the FEM model.

\subsection{FEM results}

Analysis results showed the time-dependent behaviour of gasket pressures for both flange-joint gaskets. In Figures 6 to 9, the gasket pressure distribution can be seen, showing a relatively small area that ensures the tightness of the joint. Figures $\mathbf{6}$ and $\mathbf{8}$ show the contact pressures for the assembly condition and they represent
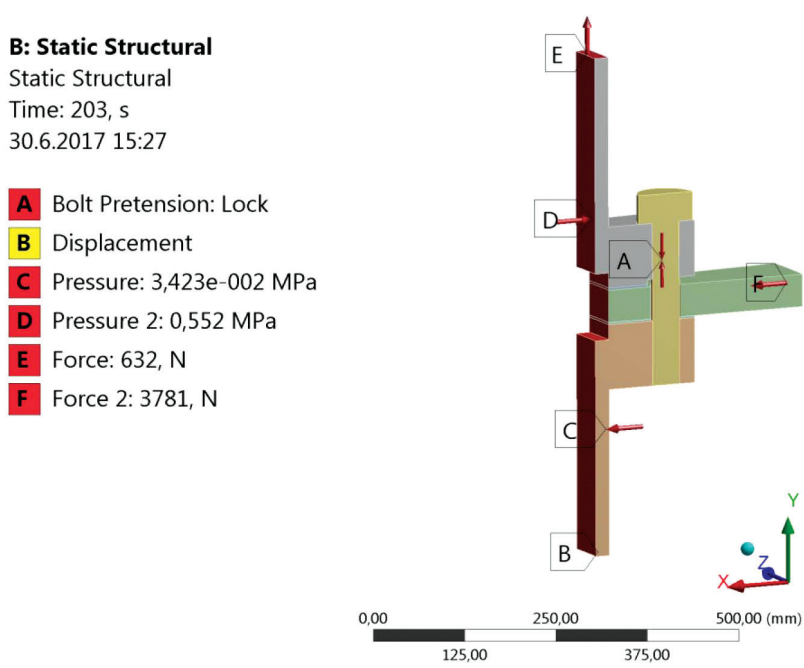

Figure 5: Static structural boundary condition
B: Static Structural

Normal Gasket Pressure 4

Type: Normal Gasket Pressure

Unit: MPa

Solution Coordinate System

4.12.2017 17:01

$-4,2366 \mathrm{Max}$

$-25,903$

$-33,181$
$-40,46$
$-47,739$

$-47,739$

$-55,018$

$-62,297$

$-69,575$
$-76,854$

$-84,133$

$-91,412$

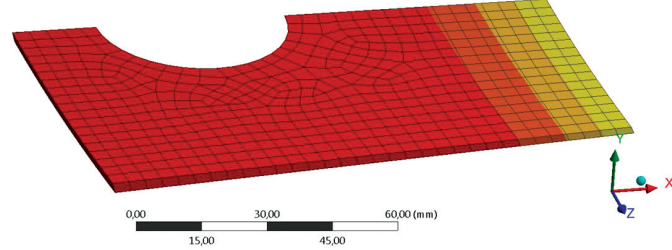

Figure 6: Contact pressure for gaskets 1 and 2 after a full bolt pretension application

the contact pressure after the tightening of the bolts to the prescribed tightening torque. Figures 7 and 9 show contact pressures after the temperature field has stabilized during the operation, and there is an evident decrease in the contact pressure. This decrease can be linked to the changes in the sealing thickness due to its behaviour according to the given material model and the changes in the pretension of the bolts caused by the

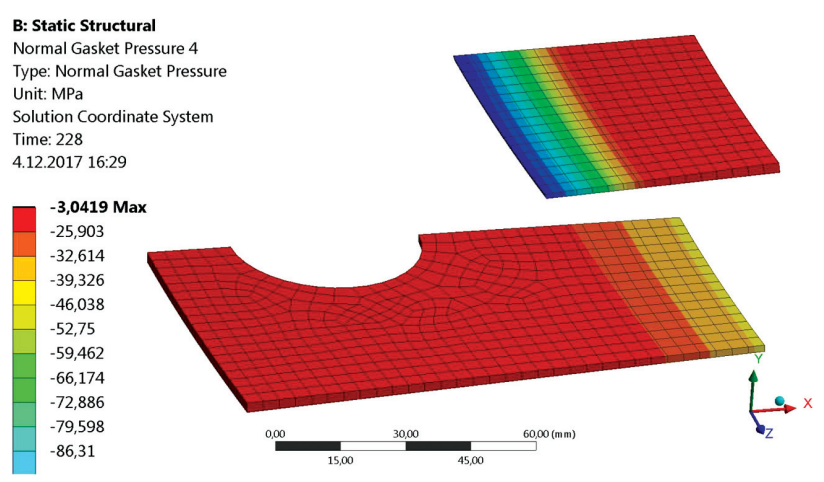

Figure 7: Contact pressure for gaskets 1 and 2 with a stabilized temperature field after the operation condition was introduced

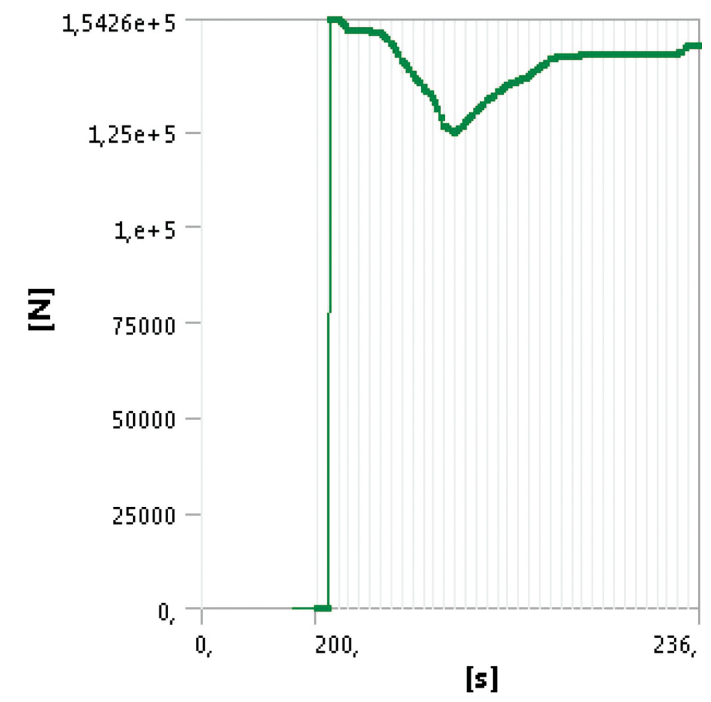

Figure 8: Bolt pretension as a time-dependent behaviour 
shape change of the flange joint after the tightening and heating.

Figure 8 describes the behaviour of the bolt pretension. First, a flange joint is assembled and bolts are tightened. Then uneven temperature distribution and pressure are introduced to the analysis. Table 2 summarizes the boundary conditions as they were used for the analysis and Figure $\mathbf{8}$ describes the corresponding behaviour of the bolt pretension.

Table 2: Time-dependent boundary conditions

\begin{tabular}{|c|c|}
\hline Time & Boundary conditions \\
\hline 201 & Full bolt pretension \\
\hline 203 & Pressures, forces \\
\hline 205 & Temperature fields \\
\hline 235 & Removal of the forces and the pressures \\
\hline
\end{tabular}

\section{CONCLUSIONS}

In the presented paper, FEM analyses of a low-pressure flange joint working in a steam power plant in Turkey is described. During the operation, leakages of the medium in the areas of sealing surfaces were observed, and a troubleshooting analysis was carried out, which consisted of checking the strength design for the proposed flange joint, checking the assembly procedures and the installation of the seals, and the leakage analysis described in this article was also carried out. The analyses were performed mainly due to a suspicion of a strong temperature influence on the flange-joint-seal integrity.

The troubleshooting analysis revealed an improper assembly procedure for gasket 2 , which was probably the main cause of the leak; however, several other factors may have contributed to the leakage as well. FEM analyses showed that an uneven temperature distribution leads to a decrease in the gasket contact pressure. As can be seen from the figures in the article, the sealing surface is not wide and the required pressure was achieved only on a small part of the gasket. Due to the simplifications of the model, additional bending moments induced by the connected piping cannot be included. A bending moment may further lower the local values of the contact pressures.

To ensure the tightness, standard EN 13445-3 Annex $\mathrm{G}$ prescribes the required bolt pretension. When temperature fields were introduced, a 6-\% decrease in the bolt pretension was observed. Although the contact pressure in the gasket was reduced because of that, it was probably not the main cause of the leak of the analysed flange joint.

\section{Acknowledgement}

The results of project NETME CENTRE PLUS (LO1202) were co-funded by the Ministry of Education, Youth and Sports within the support programme "National Sustainability Programme I".

\section{REFERENCES}

${ }^{1}$ D. R. Moss, M. Basic, Pressure vessel design manual, $4^{\text {th }}$ ed., Amsterdam, Boston: Elsevier/Butterworth-Heinemann, 2013, 813

${ }^{2}$ OhmTech: EN 1591 and EN 13445 Annex G, http://www.ohmtech.hu/ohmtech/standards/en_1591_and_en_13445 _annex_g.html, 29.6. 2017

${ }^{3}$ EN 13445-3:2014 Unfired pressure vessels (Czech ed.), Prague

${ }^{4}$ M. Krishna, M. S. Shunmugam, N. Siva Prasad, A study on the sealing performance of bolted flange joints with gaskets using finite element analysis, International Journal of Pressure Vessels and Piping, 84 (2007) 6, doi:10.1016/j.ijpvp.2007.02.001

${ }^{5}$ EN 10028-2:2010 - Flat products made of steels for pressure purposes -Part 2: Non-alloy and alloy steels with specified elevated temperature properties (Czech ed.), Prague

${ }^{6}$ EN 10025-2:2005 - Hot rolled products of structural steels - Part 2: Technical delivery conditions for non-alloy structural steels (Czech ed.), Prague

${ }^{7}$ Gasket - POWER@graf 3 PREMIUM, http://www.tesneni.cz/ cs/katalog-produktu/plochaprirubova-tesneni/tesnici-desky/expandov any-grafit-powergraf/power\%C2\% AEgraf-3-premium, 29. 6. 2017 